\title{
Core Value (Ta'āwun) in Inclusive Education Development Program
}

\author{
K. S. Komariah \\ Department of General Education \\ Universitas Pendidikan Indoensia \\ dzikrullahaja@gmail.com
}

\begin{abstract}
Regardless of its fundamental role, value cultivation or development has been neglected in the education system. This phenomenon is even more profound in inclusive schools, where it is actually much more needed. The research ultimately attempts to seek answers to the question of how core values are implemented in inclusive school development program at SDN Purtaco Indah, Bandung City. It adopted qualitative approach employing the methods of descriptive analysis, case study, grounded theory, social hermeneutics, and thematic study of Al-Quran Al-Qarafi. Data were obtained through observation, interview, questionnaire, and documentary analysis. The results show that: 1) The implementation of inclusive education is based on the religious, psychological, and pedagogic foundations of ta' $\bar{a}$ wun value development as the core value in inclusive education; 2) Hierarchically, ta' $\bar{a}$ wun value is elaborated into basic, instrumental, and practical values; 3) Ta 'āwun as the core value in inclusive education is implemented in the relationship: among teachers, between teachers and students' parents, between students and their parents, among students' parents (those of the regular and special needs students), and among students (regular and special needs); 4) The program of ta' $\bar{a} w u n$ value development has the following advantages: (a) Easier acceptance of special needs children in inclusive schools, (b) evoking the optimism of special needs children's parents, (c) creating comfort and pleasant feelings among the parents because their children can study inclusively with regular students, (d) giving opportunities for parents of special needs children who are economically disadvantaged to socialize regardless of their status; Meanwhile, the disadvantages of this program are: (a) Regular students are relatively hindered in their learning process, as teachers have to divide their attention to the special needs children with cognitive limitation, and (b) it is really difficult to convince parents of regular students to accept special needs children in the same class as their children.
\end{abstract}

Keywords- core value, ta awun value, inclusive school, inclusive education, special needs children, basic values, instrumental values, practical values

\section{INTRODUCTION}

Value cultivation is a fundamental aspect of an education system. Essentially, education is a way of humanizing human beings to be ideal beings. The ideal human being, as formulated in the objective of Indonesia's national education, is defined as a student with fully developed potentials in order to be a faithful and pious human being that will become a virtuous, healthy, knowledgeable, capable, creative, independent, democratic and responsible citizen [1].

Indonesia implements an education system that develops the personality of its nation. Every citizen, regardless of whether s/he is able or disabled physically and mentally, has equal rights to education. Hence, schools should naturally be able to serve students, both regular and special needs ones, with educational services without discriminating their physical and mental conditions.

Until the last decade, Indonesia had implemented exclusive education. Regular students were educated in regular schools, while special needs students were educated in Sekolah Luar Biasa (SLB/Special Needs School); meanwhile, in real life, the two kinds of student's live side by side. It was only in 2003 that the government of Indonesia pioneered an inclusive education program, where special needs students can learn together with regular students in regular schools. The stipulation of the Ministry of Education and Culture states that the ratio of regular to special needs students is 9:1 [2], which means that for every 9 regular students, there is one special needs student.

The implementation of inclusive education, in addition to complying with Salamanca Declaration that stresses on the importance of inclusive education in an attempt of meeting the international goal of education for all, is prompted by the large number of special needs children who did not have to opportunity to attend schools. The Vice Deputy of the Ministry of Education and Culture [3] reported that the number of special needs students who had not received education was still high. Based on the data [4], the participation rate of special needs students in primary education was only $30 \%$ of the total 356,000 children, or 106,000 . This number means that $70 \%$ of the special needs children, or around 250,000, had not received education. Hence, the ratio of 9:1 is very ideal, as it allows each special needs child to study in a school with a close proximity to his or her home. On the other hand, the various reasons why special needs children do not go to school are: (1) the inability of the closest school to provide education service for special needs children; (2) the inaccessible location of special needs schools (very far from home); (3) the parents not giving opportunities for the special needs children to study because of embarrassment of having special needs children; and (4) parents' and community's inability to understand that special needs children have to be sent to school under the framework of compulsory education [3].

Unfortunately, though, the model of inclusive education currently implemented is not well received by the majority of Indonesian people, although several research results have proved the advantages of this model, such as the values cultivated in inclusive classroom, which consist of patience, perseverance, sharing, tolerance, and solidarity among inclusive school members. In addition, the teaching and learning in inclusive classroom encourages the development of positive attitudes, such as tolerance, awareness of differences, and mutual assistance [5]. 
Inclusive State Primary School (henceforth, Indonesian SDN) Putraco Indah, in the researcher's opinion, has prominent features in its inclusive education. For instance, the inclusive school is well-trusted by the communities, such can be seen in the number of special needs children accepted in the school, which is $66 \%$, compared to the $34 \%$ of the number of regular students. This number significantly exceeds the number of special needs students to be included in one school as stipulated by the government, which is $10 \%$ of the total students in a class [7]. Furthermore, although several primary schools in Bandung City welcome special needs children, the inclusion of these children has not been well-received, such can be observed in the large number of parents or regular students who recommend the school to remove the special needs students for fear of interfering with their children's study.

Thus, how can Inclusive SDN Putraco Indah gain great trust from the communities to administer inclusive education? The answer must lie in the core values developed and programmed in the school. Departing from this question, the major question of this research is: How does SDN Putraco Indah in Bandung City implement the core values in developing inclusive education? Applying qualitative approach, this article aims to find the implementation of core values in an attempt of developing inclusive education in SDN Putraco Indah Kota Bandung.

\section{METHODOLOGY}

The research adopted qualitative approach employing the methods of descriptive analysis, case study, grounded theory, social hermeneutics, and thematic analysis of AlQuran Al-Qarafi. The location of this research was SDN Putraco Indah, Jalan Rajamantri Kaler No. 25, Lengkong District, Bandung City. The subjects consisted of the principal, Islamic education teachers, homeroom teachers, parents of special needs students, special needs students, and regular students in the school. Meanwhile, data were collected through interview, observation, documentary analysis, and library research.

The data were analyzed by reducing and checking their validity to obtain specific data on: (a) the program of ta ${ }^{~} \bar{a} w u n$ value development as the core value of inclusive education in an inclusive school; and (b) the implementation of the development program of ta'āwun value as the core value in inclusive education in SDN Putraco Indah. [6] Essentially, data analysis in qualitative research is data reduction due to the great number of available data. Qualitative data analysis is a process of compiling data based on themes and categories in order to allow for interpretation [7]. Therefore, in qualitative data analysis, the researcher has to be creative in collecting and processing the data in order to be truly meaningful.

\section{RESULTS AND DISCUSSION}

\section{A. The Foundations of Inclusive Education}

The inclusive education implemented in SDN Putraco Indah is based on religious, psychological, and pedagogical foundations of $t a^{`} \bar{a} w u n$ value development as the core value in inclusive education.

\section{Religious Foundation}

According to an informant, the religious foundation of ta 'äwun value in the inclusive school can be found in Quranic verses of Al-Hajj (22) verse 5, Al-Anfal (8) verse 28, Al-Maidah (5) verse 2, and hadiths on the virtued of mutual aid. Surah Al-Hajj verse 5 reveals that some children are born into this world in perfect conditions, while others are not. In the verse of Al-Anfal 28, it is mentioned that children are but a trial, meaning that their presence (either with or without special needs) is a form of a trial from Allah; consequently, children will elevate the dignity of parents and teachers if they give the children the best education. Then, in surah Al-Maidah verse 2 and hadiths from the Prophet SAW, the need for ta awun (mutual assistance) is stressed in its good virtues, including the implementation of inclusive education.

The verses quoted as the religious foundation are elaborated by the informant into psychological foundation. The elaboration is quite apt because, as stated above, AlHajj (22) verse 5 clearly asserts that some children are born perfectly, and some others are not. This verse is strengthened by Surah 'Abasa concerning the Blind Abdullah bin Ummi Maktum who got praised by Allah for his thirst for religious knowledge. Therefore, psychologically we have to accept that each child is unique. The first uniqueness commonly found is the existence of children with special needs among the majority of regular children. Surah 'Abasa actually also emphasizes that disabled people, like the blind, can achieve the highest dignity in God's side. This means that potentials for development can be found not only in people who are born perfectly, but also those who are physically disabled.

\section{Psychological Foundation}

Psychologically, each individual being has his or her own uniqueness that makes individuals different from one to another. According to the informant, each child is unique. Similar to regular children, special needs children are unique. For example, several blind and autistic children are very intelligent, sometimes much more intelligent than regular kids. Some special needs children are talented in arts; in fact, we often see in television how people with special needs excel in arts. In contrast, many children who are born normally end up being society's pest because of inadequate education. They turn to be beggars and homeless, and many women end up being sex workers. The phenomena show that the key to one's success is not in his or her innate condition, but education. This is where inclusive education plays its role, because each child is unique.

3. Pedagogic Foundation 
The first pedagogic foundation is that human beings are educational beings (educandum) and educable. This argument is very fitting. In the initial stage of their life, human beings are much weaker than any animal. In their childhood, they are highly dependent upon adults. But, when they mature, they develop rapidly and unpredictably. This development shows that human beings are educandum, while animals are not. In addition, human beings are educable. With the best education, many special needs children can in fact achieve their perfection just as how regular children do.

The second pedagogic foundation is Dakar Declaration of Education for All. The Declaration is made as the foundation because it, among others, holds the commitment of all nations to: guarantee that the youths' and adults' need for education will be catered to through equal access to appropriate learning and life skills programs; eliminate gender disparity in primary and secondary education by 2005 and gender equality in education by 2015 , expand education for young children, and guarantee that by 2015 all children - especially female and children with disadvantages (special needs children)will have access to complete their compulsory, free, and good quality education. Another item of this declaration is the commitment to improve all aspects of quality education and guarantee its excellence, so that recognized and measured learning results can be achieved by anyone, particularly in literacy and life skills. The Dakkar Conference, according to the informant, clearly promotes education for all, including one for special needs children.

The third pedagogical foundation is that disabled children (including physically, sensory or intellectually disabled children and those who are frequently marginalized) refer to children who are born with physical or psychological disabilities or those who become disabled due to illness, accident, or other causes. The informant further explains that disability can mean that children experience difficulties in seeing, hearing, moving, and using other parts of their body. The children, according to the informant, may learn more slowly and differently from other children, although some of them may have more strengths than regular children. In reality, disabled children are capable of learning and have the same right to attend schools, just like the regular children, but they are often separated into a special school for special needs children (Indonesian, SLB), while they actually can learn in regular schools.

\section{B. The Core Value Developed in Inclusive Education in SDN Putraco Indah}

Ta 'a $\bar{w}$ wun value as one of the findings of this research is hierarchically elaborated into basic values, instrumental values, and practical values. The basic values hierarchically consist of tolerance, sympathy, and empathy; the instrumental values comprise assistance, cooperation, and at the top position is ta'a wun (mutual assistance with the intention of lillahi Ta'ala). The elaboration of ta'âwun value is quite adequate, as in practicing ta ${ }^{\prime}$ awun the three basic values and two instrumental values are needed as the initial stages that lead to the ultimate value of ta'awun.

The development of ta'âwun value in inclusive education in SDN Putraco Indah Kota Bandung is not instantly and simultaneously done. It is a series of long term experiments since the school was first stipulated to administer inclusive education in Bandung City. It is from this long experience that a set of values are established and developed hierarchically, from tolerance, sympathy, empathy, followed by the values of assistance, cooperation, and finally it achieves the ultimate value of ta'a ${ }^{\prime}$ wun (mutual assistance with the intention of lillahi Ta'ala). According to the primary informant, the ultimate value of ta' $\bar{a}$ wun will not be realized without the development of a set of underpinning values. The informant further explains the set of values as follows:

First, to realize the core value of ta'āwun, the basic value of "tolerance" should be first cultivated. It means that ta 'āwun should be established based on tolerance. In the context of inclusive schools, ta' $\bar{a}$ wun realized in the school should allow for special needs children to be well-accepted. Similarly, special needs children should be able to accept the regular children within the same school and classroom. Without tolerance, inclusive education will not be successful. The word "tolerance" means having the trait or attitude of respecting (appreciating, letting, allowing) a stance (opinion, view, belief, habit, behavior, etc.) that is different or in opposition to one's own stance [8]. It is further explained that "tolerance" is a term found in social, cultural, and religious contexts [9]. Tolerance means an attitude and action that is against discrimination of different groups or groups that cannot be accepted by the majority. In relation to inclusive schools, tolerance means the attitude and action that is against discrimination of special needs children who are in general not well-accepted by both regular children and their parents. So, the informant's view is relevant, as s/he sees the value of "tolerance" as the first element of the core value of "ta 'âwun" in inclusive schools. Without tolerance of regular students and their parents, special needs children will be rejected. Even if the school accepts them, their existence will be considered a hindrance to both regular students and their parents. In response to the less effective implementation of inclusive schools, Idayu - as a person who directly manages an inclusive school in Malang City-says that the less effectiveness is caused by the fact that the majority of the people do not welcome special needs children.

Secondly, ta'äwun has the meaning of being "sympathetic", meaning that in ta'âwun sympathy is necessary, translated as the ability to be aware and able to feel the difficulties experienced by special needs children, just like how regular students will. As regards inclusive schools, ta'âwun is realized by being able to feel the difficulties experienced by other students. Regular students should be able to feel the difficulties of special needs students. The same is true for special needs students who have to be able to feel the 
difficulties of regular students. Without sympathy, inclusive education in schools is impossible. The informant's definition of "sympathy" is right, as this word with "sympathetic" as the adjective means first, affection, agreement (with), and favor; and second, feeling what other feel. So, the informant's argument that in practicing ta 'âwun "sympathy" is required is correct, especially the sympathy of regular students for special needs ones [8]. Eventually, there will be a mutual relationship, where special needs children will sympathize with the regular students.

Third, ta'āwun means "empathy", meaning that ta 'āwun necessitates an empathic soul, or the ability to feel the difficulties of special needs children, and they will be encouraged to help ease the problems experienced by the special needs children. The same is true for the special needs children. With regard to inclusive school, ta 'âwun realized in the school should encourage children to feel others' difficulties, and later on the children will be driven to give help to those with personal difficulties or difficulties related to inclusive education. Without an emphatic soul, inclusive education in school is impossible.

The word "empathy" has the meaning of being able to encounter other's feeling and thoughts [8]. It is the ability that is defined differently and encompasses a wide spectrum, concerning others; creating a desire to help each other, to experience other's emotion, to know what others feel and think; and blurring the boundary between self and other [10]; meanwhile, it is also said that "empathy" means "physical attraction". It can be defined as complex affective and cognitive reactions to other's emotional distress [11]. Empathy is considered as the ability to feel other people's emotions, to sympathize and try to solve problems, as well as taking other people's perspectives. In the context of inclusive school, empathy means the attitude of the regular students (and their parents) in feeling the personal and learning difficulties of special needs children (as well as their parents), thereby creating a desire to help the special needs children. This desire eventually is dependent upon each of the regular students in practice. Thus, the informant's view is very appropriate that the two values of "sympathy" and "empathy" are the embodiment of the dual values of the core value of ' $t a$ ' $a \overline{w u n}$ ' after the value of "tolerance" in inclusive schools. Without the values of "sympathy" and "empathy" from regular students and their parents, the special needs students will not feel the difference of the inclusive school from the special needs school. Alternatively, physically the special needs children will learn in an inclusive school but psychologically they will feel they are learning in a special needs school. The strength of this ta 'äwun value in inclusive schools is made possible because of the values of tolerance, sympathy, and empathy. However, the three values do not suffice. The primary informant is fitting by including the fourth and fifth elements of the core value of ta'âwun, namely "cooperation" and "assistance".

Fourth, ta'âwun has the meaning of "giving assistance", more particularly it means that in ta 'äwun, there should be instrumental values of "giving assistance", where the regular students must assist the special needs ones; the same applies for the special needs students who have to help the regular students. This argument is probably rather irrational at first glance because instead of mutual assistance, it is much possible that the regular students will provide help for the special needs ones.

Fifth, ta'āwun also means "cooperation”, in which it must contain the element of cooperation, where regular students must cooperate with the special needs students, and vice versa. According to the key informant, this argument is probably not very acceptable because it is more possible that what happens is the regular students provide help for the special needs ones. To buttress the argument, the informant explains that special needs students also have strengths (for instance, they excel in arts, are very diligent in helping clean the classroom, such as sweeping or mopping the floor and the yard, and are generous). Meanwhile, the strengths of regular students lie in their physical and mental perfection. Nevertheless, they also have their own weaknesses just like the special needs students do; therefore, cooperation is needed, although the weaknesses of special needs children are naturally more conspicuous. Regarding inclusive school, the ta' $\bar{a}$ wun realized in the school should be able to develop "cooperation" among all students, ultimately between the regular and special needs students. Without cooperation, inclusive education in schools will not run smoothly.

It can be argued that the informant's opinion is very fitting that the development of the ultimate instrumental value of "ta 'awun" follows that of the basic values of tolerance, sympathy, and empathy; hence, the values of "providing assistance" and "cooperation" should also be developed in inclusive schools. Without these two values cultivated among regular students and their parents, special needs children will feel that they are physically learning in an inclusive school, but psychologically they are in a special needs school. The strength of ta'âwun value in an inclusive school is made possible by the basic values of tolerance, sympathy, and empathy, followed by the instrumental values of "providing assistance" and "cooperation". These values are essentially a single entity, where the latter values are especially inseparable.

\section{The Implementation of Ta'āwun Value Development Program as the Core Value in Inclusive Education}

The implementation of ta'äwun value development program as the core value in inclusive education in SDN Putraco Indah encompasses: (1) The implementation of ta 'âwun value development program among teachers, (2) The implementation of ta'āwun value development program between teachers and students' parents, (3) The implementation of ta'āwun value development program between parents and students, (4) The implementation of ta'äwun value development program between parents of regular and special needs students, and (5) The implementation of ta'āwun value development program between regular and special needs students. 
The program of ta'āwun value development in SDN Putraco Indah Bandung City starts with extension program for teachers, followed by teachers extending the program to parents and students. Afterwards, parents practice $t a^{`} \bar{a} w u n$ to students, both the regular and special needs one, and followed by habituation of this value among students' parents and between regular and special needs students.

There are several factors determining the success of inclusive education [12]. In planning inclusive education, understanding the concept is not sufficient. A plan should be made appropriately and realistically. The determining factors to be considered for the success of a long term implementation of inclusive education are: (1) a solid framework, (2) implementation based on local culture and context, and (3) continuous participation and critical self-reflection.

The first is a solid framework [12], where the emphasis is on the word "frame or skeleton". Inclusive education should be supported by a framework of values, beliefs, principles, and indicators of success. This framework will develop along with the implementation and does not necessarily have to be perfect since the beginning. However, if the parties involved have conflicting values (and other conflicts), and the conflict is not realized and solved, inclusive education will collapse. It appears that the program of ta 'âwun in SDN Putraco Indah has a strong framework, namely ta 'âwun value, as can be seen in the ten-year implementation of the program, although government's aid for the program, which was actually designated as a pilot project, was terminated in 2007.

The second factor is local culture and context [13]. Situmorang asserts that they keyword is the "flesh". Inclusive education is a blue print. One of the major mistakes is the assumption that a solution adapted from a certain culture/context can solve the problem of another culture/context, which is dissimilar in many ways. Again, experience has shown that a solution should be developed locally by taking advantage of local resources. Any solution not developed this way will not survive in a long term. The implementation of ta 'äwun program in SDN Putraco Indah seems to have a fresh "flesh", namely the value of ta'āwun cultivated (developed) in accordance with the local value. It can be proven by how SDN Putraco Indah is very well-trusted by the communities. The trust is manifested in the number of special needs students that attend this school, reaching almost $50 \%$ of the whole student population, significantly exceeding the proportion of $10 \%$ per class recommended by the government.

The third factor determining the success of inclusive education is continuous participation and critical self-reflection [12]. Situmorang uses "the blood of life" as the analogy for this factor. Inclusive education will not succeed if it is a dead structure; instead, it has to be a dynamic process. For inclusive education to thrive, sustainable participation involving all stakeholders in a critical self-reflection is needed. Indeed, one core principle of inclusive education is being responsive to diversity, which is ever changing and unpredictable. Therefore, inclusive education must thrive. The three factors (skeleton, flesh, and blood) simultaneously form a strong living organism, which can adapt with and grow in a local culture and context.

SDN Putraco Indah in Bandung City has developed a design of ta'āwun value development program as the core value in inclusive education. With this design, teachers have clear guidelines on how to develop ta'āwun in SDN Putraco Indah, Bandung City. It should be understood that an inclusive school is different from a regular school. The main difference lies in the students. In regular schools, there are only regular students and in SLB there are only special needs children; meanwhile, in an inclusive school, there are both regular and special needs students. Therefore, inclusive schools require appropriate input to support the success of their inclusive education. Teachers are the first and ultimate capital in the cultivation (implementation) of ta'âwun program in inclusive schools. Thus, they should have equal knowledge, insight, and skills in developing the ta 'âwun program.

Theoretically, an inclusive school needs a special guidance teacher, namely a teacher whose main role is to give more attention to students in inclusive schools and is capable of managing students with special needs. In this regard, Scott stated that "the success of the inclusive education depends, to a large extent, on the willingness and the ability of teachers to make accommodations for individuals with special needs" [13]. The statement stresses that the success of inclusive education is highly dependent upon the teachers' desire and abilities to accommodate special needs students' needs. He further explained that a teacher's job in inclusive education is to educate, teach, guide, direct, train, assess, and evaluate students in early childhood education, formal education, primary and secondary education in schools administering inclusive education [14].

By taking the design as the guidelines for the program, the teachers can implement ta 'āwun value more easily. Based on the findings, it is found that the teachers have extended this program to students and their parents. Subsequently, the parents implement ta 'äwun value to their children (both regular and special needs students) and to other parents (both of regular and special needs students). The parents also implement 
ta ${ }^{\circ} \bar{w} w n$ in their relationship with the school, such as by helping to invite an ustadz (Islamic term for teacher), aided by other teachers, to teach how to read and write Al-Quran to both regular and special needs students who have not been able to read Al-Quran.

Another interesting aspect to be further discussed in SDN Putraco Indah is the development of inclusive education through peer tutoring. These peer tutors are students who better comprehend the materials in inclusive education. They help the teachers in teaching the concepts of subject matters that both special needs and regular students have not understood well. The implementation of inclusive education through peer tutoring shows that when given trust, children can do their tutorial tasks well.

\section{The Advantages and Disadvantages of Ta'āwun Value Development Program as the Core Value of Inclusive Education in SDN Putraco Indah}

The advantages of the ta'äwun value development program as the core value of inclusive education in SDN Putraco Indah are:

1. Easy acceptance of special needs students in the inclusive school. In majority, regular students are not prepared to accept special needs students. It is common that even when there is only or two special needs students in a school, parents of regular students will express their disagreement to the school and urge the school to expel the students. However, with the cultivation of ta' $\bar{a}$ wun value, regular students and their parents can welcome special needs students with open heart, just like how they accept regular students.

2. Parents of special needs children often complain about their children; however, with the cultivation of $t a^{\prime} \bar{a} w u n$ in the school, these parents become more optimistic. They come to be aware that the value of a child lies not in his or her innate perfection, but more in personality and virtues. There are many cases where special needs children turn into useful adults that benefit greatly for humankind.

3. Parents of special needs children are pleased because their children can learn inclusively together with regular students. Different from the exclusive school, where children feel as if they are in a hospice or a kind of hospital, in an inclusive school the parents can see how their children are happy to socialize and learn with children from various backgrounds. Their children can feel how big the world is, so that gradually they will be able to eliminate the feeling of lacking in them. They will eventually feel that they are not different from the regular children.

4. Parents of special needs children from the higher economic status who used to socialize only with other parents of the same economic status can realize how people who are often regarded as low because of their economic status can actually be loyal friends. Similarly, parents of regular students can benefit from the cultivation of ta 'âwun value in the inclusive school. They can interact closely with people who are advantaged economically and used to be living exclusively (they only want to interact with equally rich people). Moreover, friendship is built between parents of regular students (who in general come from lower economic status) and parents of special needs children (who commonly have higher economic status), so that social division on the basis of economic status is eliminated in an inclusive school.

Meanwhile, the disadvantages are as follows:

a. In terms of knowledge transfer, regular students may encounter some obstacles in receiving knowledge from teachers, because the teachers should divide their attention to the special needs children with limited cognitive abilities.

b. It is very difficult to convince parents or regular students to accept special needs children to learn together in the classroom with the children.

The program of ta āwun value development in SDN "Inclusive" Putraco Indah has become a highly invaluable social asset. The disadvantage of this program lies only in the (delayed) knowledge transfer for regular students that is not as efficient as in regular schools. Nevertheless, observing the alumni of this school in their secondary education, both in junior high and senior or vocational high schools, it is found that the regular students develop as well as students from regular schools. This means that the delayed transfer of knowledge or the lag is only temporary. In fact, the advantages are more prominent. Based on an interview with the informant, for example, it is found that graduates of SDN "Inclusive" Putraco Indah excel in affective dimension. They show tolerance, sympathy, empathy, willingness to help, and cooperation more than any other children.

\section{ACKNOWLEDGMENT}

The writer would like to express her gratitude to the Study Department of General Education, the School of Postgraduate Studies of Indonesia University of Education.

\section{REFERENCES}

[1] Law No. 20 of 2003 concerning National Education System

[2] The Decree of the Minister of National Education No. 70 of 2009 concerning Inclusive Education for Students with Disabilities Special Talents.

[3] Anonymous. 2013. 184 ribu anak berkebutuhan khusus belum nikmati pendidikan. Available at. [Online] http://www.antaranews.com/berita/395235/184-ribu-anakberkebutuhan-khusus-belum-nikmati-pendidikan.

[4] Direktorat Pembinaan PK-LK Dikdas. (2010). Pelaksanaan administrasi Direktorat Pembinaan PK-LK Dikdas. Jakarta

[5] Rahardja, Pratama. 2010. Teori Mikroekonomi. Jakarta: LP-FEUI.

[6] L.J. Moleong. (1991). Metodologi Penelitian Kualitatif. Bandung: Remaja Rosdakarya.

[7] Nasution, 1988. Metode Penelitian Naturalistik dan Kualitatif. Bandung. Tarsito.

[8] KBBI, Daring. 2008. Memeras. Retrieved February 16, 2011 from http://pusatbahasa.depdiknas.go.id/kbbi/index.php 
[9] P. Zagorin. (2003). Pengertian Toleransi. Available at: http://id.wikipedia.org/wiki/Toleransi [15 Mei 2013]

[10] Hodges \& Klein. (2001). Regulating the Costs of Empathy: The Price of Being Human. Journal of Socio Economics 30 (2001) 437-452.

[11] Baron \& Byrne. (2004). Social Psychology (10 $10^{\text {th }}$ ed). USA: Pearson.

[12] Situmorang, Jamisten (2008), available at: http://jamisten.wordpress.com/2008/12/10/ pendidikan-inklusi

[13] Indriawati, P. (2013). Implementasi Kebijakan Tugas Guru Pembimbing Khusus pada Pendidikan Inklusif di SD Negeri se-Kecamatan Junrejo Batu. Jurnal Kebijakan dan Pengembangan Pendidikan , 1 (1), 49-55.

[14] Dewi S.L dan Paramita P.P. (2013). Tingkat Burnout Ditinjau dari Karakteristik Demografis (usia, jenis kelamin, masa kerja) Guru SDN Inklusi Surabaya. Jurnal Psikologi Pendidikan dan Perkembangan , 2 $(1), 1-9$. 